\title{
APRESENTAÇÃO DA SEÇÃO DE ENSINO DA HISTÓRIA
}

\section{AleXANDRE Guilherme dA CRuz Alves Junior*}

É com grande satisfação que a revista Fronteiras \& Debates inaugura a seção Ensino de História, que passará a compor de modo permanente as suas próximas edições. A seção terá como objetivo trazer aos seus leitores artigos que busquem estimular importantes reflexões acerca do processo de ensino-aprendizagem da História, a partir de múltiplas perspectivas, englobando temáticas como o Ensino de História e suas metodologias; didática e ensino-aprendizagem em História; o Ensino de História em diferentes espaços; Estágio e Currículo de História; formação docente e perspectivas discentes. Os artigos destinam-se aos discentes dos cursos de História, docentes de todos os níveis de ensino, e a todos/as que compartilham interesse pelo Ensino de História, trazendo aos leitores, tanto resultados de pesquisas, como relatos de experiências didático-pedagógicas e reflexões teórico-metodológicas.

Na Universidade Federal do Amapá, o início do curso de Mestrado Profissional em Ensino de História (ProfHistória), no ano de 2016, apresenta-se como um importante esforço institucional no sentido de promover e ampliar os debates acerca da prática docente, colaborando para superar uma antiga e preconceituosa visão na qual a universidade seria o lócus privilegiado da produção do conhecimento histórico, cabendo aos docentes da Educação Básica o papel secundário de meros reprodutores de tais conhecimentos em sala de aula.

Neste sentido, a seção Ensino de História apresenta-se como um espaço de diálogo entre docentes/pesquisadores que atuam tanto em centros universitários como em escolas da Educação Básica, valorizando, portanto, trabalhos que conjuguem reflexões teóricas e práticas docentes em seus múltiplos aspectos.

Na presente edição, a seção contará com artigo de Larissa Viana, O Atlântico negro: narrativas acadêmicas e questões para o ensino de História das Américas, onde a autora, ao analisar a trajetória de quatro intelectuais pioneiros nas temáticas do A-

\footnotetext{
* Doutor em História pela Universidade Federal Fluminense. Atualmente é professor de História da América na Universidade Federal do Amapá (Unifap/ Campus Binacional do Oiapoque) e professor do Mestrado Profissional em Ensino de História (ProfHistória) da Unifap. E-mail: alexandrecruzunifap@ gmail.com
} 
tlântico negro - C. L. R. James, Eric Williams, Carter Woodson e W.E.B. Du Bois -, pretende identificar problemas e temas relevantes para o Ensino de História a partir da temática do Atlântico negro, tendo como norte o enfrentamento de questões sensíveis em sala de aula, como o racismo.

Flávio Trovão, em Hollywood em sala de aula: reflexões sobre cinema e ensino de História, busca analisar a grande influência das produções cinematográficas hollywoodianas em sala de aula, debatendo as implicações políticas e estéticas da forte penetração cultural fílmica norte-americana, com destaque para o papel da construção da noção de juventude, diante de uma cultura midiática cada vez mais homogênea e globalizada.

Em Os Relatos de viagem do século XIX como fontes históricas para a prática do ensino de História da América: algumas considerações teórico-metodológicas, Carla Viviane Paulino busca discutir os possíveis tratamentos e análises dos relatos de viagens como fonte documental para o professor de História, tecendo considerações teórico-metodológicas sobre o trabalho com esse tipo de documento.

Ana Marcela França, em $O$ uso de iconografias em sala de aula: as impressões de alguns viajantes sobre os biomas brasileiros, discute os principais aspectos da formação da histórica do Brasil através das imagens, partindo da experiência de um curso ministrado pela autora. Neste sentido, Ana Marcela argumenta como através das iconografias de paisagem e dos relatos de viajantes, na primeira metade do século XIX, foi construída uma imagem do Brasil a partir da diversidade de sua natureza, resultando em uma identidade que perdura até os dias de hoje.

Desejamos uma boa leitura. 